\title{
ANALISA LOGAM BERAT PADA AIR MINUM DALAM KEMASAN (AMDK) YANG DIPRODUKSI DI KOTA BATAM
}

\section{ANAL YSIS OF HEAVY METAL ON BOTTLED MINERAL WATER (AMDK) PRODUCED IN BATAM CITY}

\author{
Fitrah Amelia ${ }^{1}$, Rahmi $^{2}$ \\ ${ }^{1}$ Prodi Pendidikan Matematika, FKIP, Universitas Riau Kepulauan, Batam-Indonesia \\ ${ }^{2}$ Prodi Pendidikan Biologi, FKIP, Universitas Riau Kepulauan, Batam-Indonesia. \\ 1e-mail: fitrahamelia@yahoo.com
}

\begin{abstract}
Abstrak
Kurangnya air bersih di wilayah kota batam khususnya dan Kepulauan Riau umumnya, membuat masyarakat lebih cenderung mengkonsumsi Air Minum dalam kemasan (AMDK) atau Air Minum Isi Ulang (AMIU) untuk kebutuhan air minum sehari-hari. Penelitian ini bertujuan untuk mengukur kadar cemaran logam yang terdapat dalam produk-produk air minum dalam kemasan yang hasilnya kemudian di bandingan dengan standar nasional indonesia (SNI) 01-3553-2006 tentang air minum dalam kemasan. Penelitian ini merupakan penelitian non eksperimental, dengan teknik pengambilan sampel purposive sampling. Tahap penelitian ini meliputi pengambilan sampel, penentuan $\mathrm{pH}$, dan analisa logam. Analisa logam dilakukan mengunakan ICPE-9000 merk shimadzu. Hasil penelitian yang dilakukan terhadap 8 merk AMDK, didapatkan 1 merk mengandung logam berat Cd yang melebihi standar yang telah di tetapkan standar nasional indonesia (SNI) 01-3553-2006 tentang air minum dalam kemasan, sedangkan untuk logam $\mathrm{Pb}$ dan $\mathrm{Cu}$ tidak melebihi ambang batas yang telah di tentukan.
\end{abstract}

Kata Kunci: AMDK, Logam Berat, ICPE-9000

\section{Abstract}

The lack of clean water in the batam city area in particular and Riau Islands in general, makes people more likely to consume bottled drinking water (AMDK) or drinking water refill (AMIU) for daily drinking water needs. This study aims to measure the levels of metal contamination contained in bottled drinking water products which results are then comparable with Indonesian national standard (SNI) 01-3553-2006 about bottled drinking water. This research is non experimental research, with technique sampling purposive sampling. The research stages include sampling, pH determination, and metal analysis. Metal analysis was performed using ICPE-9000 shimadzu brand. The results of the research on 8 brands of AMDK, found 1 brand containing heavy metal Cd that exceeds Indonesia National Standard (SNI) 01-3553-2006 about bottled drinking water, while for metal $\mathrm{Pb}$ and $\mathrm{Cu}$ does not exceed the threshold which has been specified.

Keywords: AMDK, Heavy metals, ICPE-9000 


\section{PENDAHULUAN}

Batam merupakan salah satu wilayah gugusan kepulauan yang ada di Indonesia. Kondisi ini membuat masyarakat batam kesulitan dalam memperoleh sumber mata air untuk kebutuhan air bersih. Oleh karena itu masyarakat lebih cenderung mengkonsumsi Air Minum dalam kemasan (AMDK) atau Air Minum Isi Ulang (AMIU) untuk kebuuhan air minum sehari-hari. Oleh karena itu, kualitas air untuk air minum harus mendapatkan perhatian utama. Air yang digunakan untuk air minum harus memenuhi berbagai persyaratan diantaranya secara fisik, air tidak berwarna, berasa dan berbau. Selain itu, air minum yang dikonsumsi harus higienis dan kandungan mikroba dan unsur logam di dalamnya tidak melewati ambang batas yang diperbolehkan. Unsur logam pada konsentrasi tinggi dapat bersifat toksik, sebaliknya pada konsentrasi yang rendah unsur logam bermanfaat dalam proses metabolisme (Stasys dkk, 2004).

Oleh karena itu, penentuan unsur logam dalam air minum dalam kemasan layak menjadi perhatian dalam rangka menjaga kualitas air minum dalam kemasan. Seperti diketahui, air minum dalam kemasan diperoleh dari berbagai proses pengolahan yang mungkin saja dalam prosesnya terkandung unsur-unsur logam yang dapat larut dalam air dan meningkatkan kadar unsur logam dalam air minum sehingga dapat bersifat toksik bagi tubuh manusia. Selain itu sumber air bersih yang digunakan dalam memproduksi air kemasan yang tidak sesuai dengan kriteria dalam pengolahan air minum.

Air merupakan zat esensial bagi kehidupan. Air dengan rumus kimia $\mathrm{H}_{2} \mathrm{O}$ adalah benda tak berwarna, tak berbau, dan tak berasa yang diperlukan oleh semua kehidupan di bumi. Secara alami air mengandung berbagai macam zat yang larut di dalamnya seperti unsur-unsur hara dan garam-garam mineral (Sudjoko, dkk, 2012).

AMDK adalah air yang telah diolah dan dikemas serta aman untuk dikonsumsi. Air minum dalam kemasan harus memenuhi persyaratan air minum dalam kemasan (AMDK) yang diatur sesuai dengan Standar Nasional Indonesia (SNI) nomor SNI-01-3553-2006. Hingga saat ini keberadaan AMDK sangat diminati oleh masyarakat karena dinilai lebih higenis dan praktis untuk memenuhi kebutuhan air minum sehari - hari. Sampai tahun 2010 tercatat sebanyak 567 perusahaan AMDK di Indonesia mampu menjual air minum sebanyak 13,5 liter per tahun. Pemanfaatan AMDK sangat dirasakan oleh masyarakat, karena AMDK merupakan solusi bagi masyarakat untuk mengkonsumsi air siap pakai (Amrih, 2005).

Menurut Kementrian Negara Kependudukan dan Lingkungan Hidup, toksisitas logam berat dapat dibagi ke dalam 3 kelompok, yaitu bersifat toksik tinggi yang terdiri dari atas 
unsur-unsur $\mathrm{Hg}, \mathrm{Cd}, \mathrm{Pb}, \mathrm{Cu}$, dan $\mathrm{Zn}$, bersifat toksik sedang terdiri dari unsur-unsur $\mathrm{Cr}, \mathrm{Ni}$, dan Co, dan bersifat tosik rendah terdiri atas unsur Mn dan Fe. Taraf toksisitas logam berat sangat beragam bagi berbagai organisme, tergantung dari berbagai aspek yang antara lain spesies, cara toksikan memasuki tubuh, frekuensi dan lamanya paparan, konsentrasi toksikan, bentuk dan sifat fisika/kimia toksikan serta kerentanan berbagai spesies terhadap toksikan (Soemirat, 2004).

Timbal $(\mathrm{Pb})$ adalah jenis logam lunak berwarna coklat kehitaman dan mudah dimurnikan. Senyawa timbal diketahui menyebabkan hipertensi, ketidaknormalan reproduksi dan menyebabkan penyakit yang berhubungan dengan saraf (Jarub, 2003). Menurut Darmono (1995), Pb yang masuk ke dalam tubuh dapat menyebabkan toksisitas pada sel darah merah, jaringan lunak (ginjal dan hati), tulang, dan jaringan keras (gigi dan tulang rawan).

Kadmium (Cd) adalah logam inorganik yang lunak, berwarna putih kebiru-biruan dan beracun. Merupakan bahan toksik dan mengakibatkan penyakit itai-itai (Mukono, 2010). Keracunan kadmium ringan dapat menyebabkan perut mual, muntah-muntah, diare, luka hati, syok dan gagal ginjal, sedangkan keracunan berat menyebabkan sakit ginjal, liver, tulang rapuh dan kerusakan sel-sel darah (Jarub, 2003). Tembaga $(\mathrm{Cu})$ adalah logam merah muda, yang lunak, dan dapat ditempa dan liat. Keracunan kronis tembaga $(\mathrm{Cu})$ dapat mengurangi umur, menimbulkan berbagai masalah reproduksi dan menurunkan fertilitas (Widowati, 2008).

Tujuan penelitian ini adalah Untuk menghitung kadar logam yang terdapat dalam produk-produk air minum dalam kemasan yang di analisa sesuai dengan peraturan menteri kesehatan RI nomor 907/MENKES/SK/VII/2002 tentang syarat-syarat untuk pengawasan kualitas air minum dan SNI 01-3553-2006 tentang air minum dalm kemasan.

\section{METODOLOGI}

Bahan kimia yang digunakan meliputi larutan standar $\mathrm{Cu}$, larutan standar $\mathrm{Pb}$, larutan standar $\mathrm{Cd}, \mathrm{HNO}_{3}$ dari Merck dengan grade p.a.dan air demin. Sedangkan alat yang digunakan meliputi peralatan gelas, kertas saring Whatman no. 41, ICPE-9000 Merk Shimadzu. 
Analisis logam berat tembaga, timbal dan kadmium dilakukan menggunakan ICPE9000 merk shimadzu. Metode analisis logam mengacu pada SNI 6989.16: 2009 untuk logam kadmium, SNI 6989.6:2009 untuk logam tembaga dan SNI 6989.8:2009 untuk logam timbal.

\section{PEMBAHASAN}

\section{Logam Cadmium (Cd)}

Kadmium (Cd) adalah logam inorganik yang lunak, berwarna putih kebiru-biruan dan beracun. Merupakan bahan toksik dan mengakibatkan penyakit itai-itai (Mukono, 2010). Logam kadmium (Cd) dikenal sebagai logam beracun setelah logam merkuri. Analisa logam cadmium (Cd) dilakukan dengan menggunakan ICPE-9000 merek shimazu. Dari dasil analisa di peroleh data sepetri pada Gambar 1. Berikut:

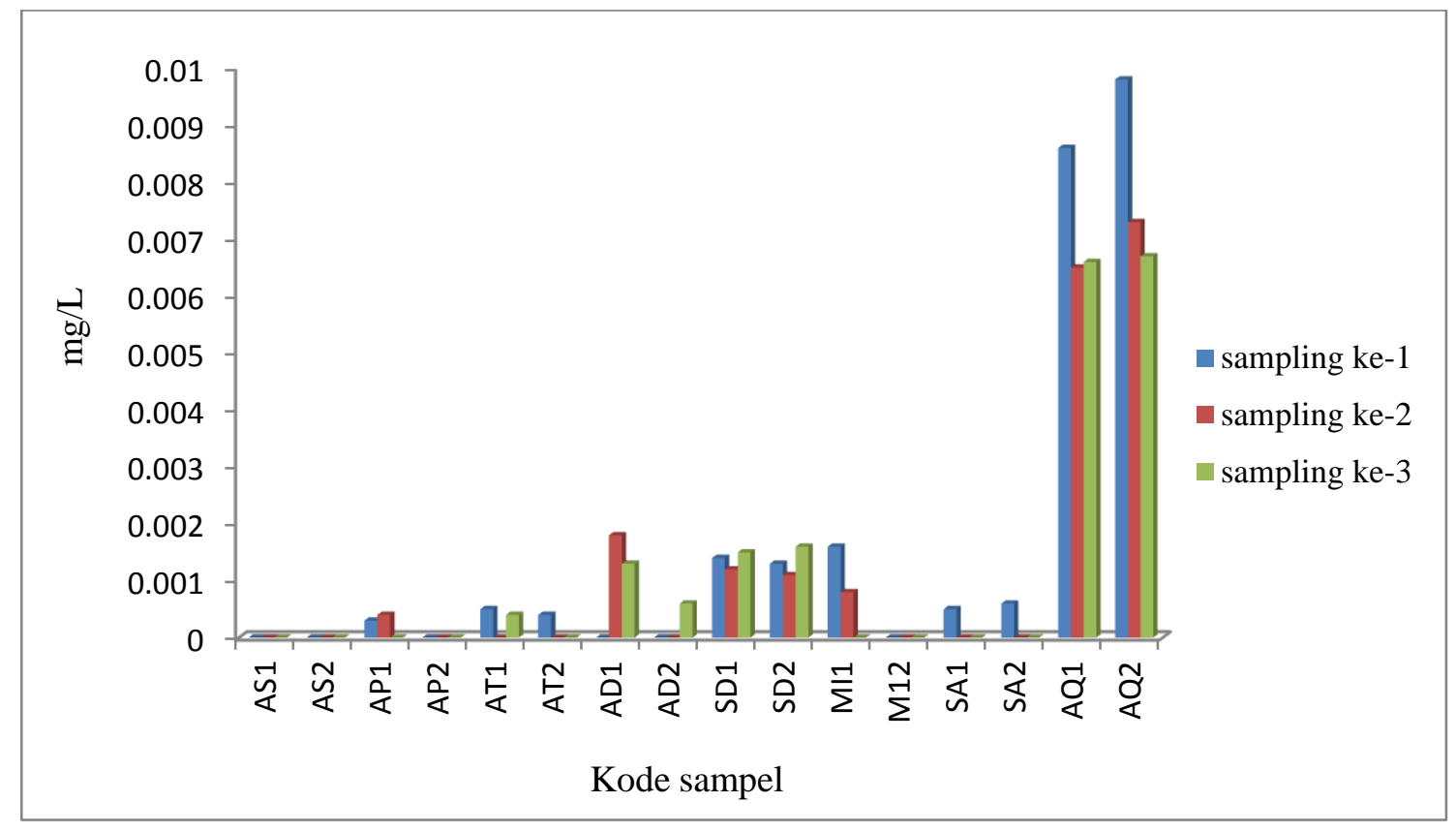

Gambar 1. Hasil analisa Logam Cd

Hasil pengukuran logam $\mathrm{Cd}$ dari beberapa merek air minum dalam kemasan diperoleh kadar logam tertinggi terdapat pada merek AQ. Dari tiga kali sampling dengan dua kali pengulangan semua hasil pengukuran kadar logamnya tetap dinyatakan tinggi. Sehingga dapat disimpulkan dari hasil yang diperoleh yang terlihat pada gambar 1 di atas diketahui bahwa AMDK merek AQ melebihi standar nasional indonesia (SNI) 01-3553-2006 tentang air minum dalam kemasan yaitu untuk Logam Cd 0,003 mg/L untuk air mineral. 
Kandungan logam Cd yang melebihi batas maksimum yang di tetapkan akan menyebabkan keracunan cadmium. Keracunan kadmium ringan dapat menyebabkan perut mual, muntah-muntah, diare, luka hati, syok dan gagal ginjal, sedangkan keracunan berat menyebabkan sakit ginjal, liver, tulang rapuh dan kerusakan sel-sel darah (Jarub, 2003). Pengaruh logam kadmium pada tubuh dapat mengakibatkan naiknya tekanan darah (Anonim, 2004). Di samping itu logam kadmium mudah larut dalam air. Terakumulasinya logam berat dalam organ tubuh dapat menyebabkan kerusakan reproduksi, anemi dan lain-lain (Darmono, 1995).

\section{Logam Timbal (Pb)}

Timbal $(\mathrm{Pb})$ merupakan logam yang bersifat neurotoksin yang dapat masuk dan terakumulasi dalam tubuh manusia sehingga berbahaya terhadap tubuh. Hasil analisa logam $\mathrm{Pb}$ dalam air minum dalam kemasan dapat dilihat pada gambar 2 di bawah ini.

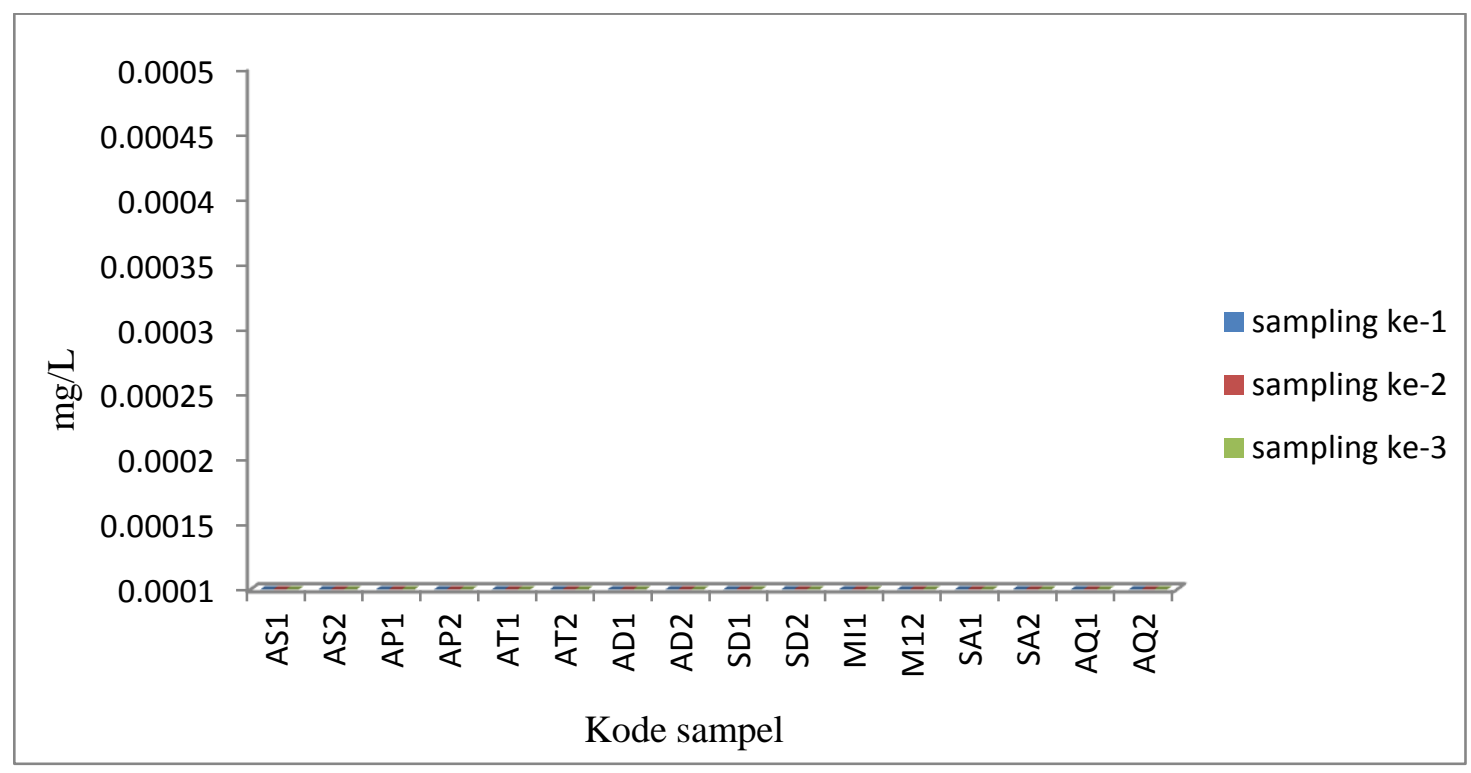

Gambar 2. Hasil analisa Logam $\mathrm{Pb}$

Berdasarkan hasil yang di peroleh, dapat dilihat pada gambar 2 di atas dapat disimpulkan bahwa semua merek air minum yang di analisa tidak melewati syarat yang telah di tentukan SNI untuk air minum dalam kemasan yang layak untuk dikonsumsi yang bebas dari cemaran logam $\mathrm{Pb}$ yaitu maksimal sebesar 0,005 mg/L, dimana berdasarkan penelitian logam $\mathrm{Pb}$ yang terkandung dalam setiap sampel untuk semua merek sebesar $<0,0001 \mathrm{mg} / \mathrm{L}$. 


\section{Logam Tembaga $(\mathrm{Cu})$}

Logam dalam kadar tertentu dalam air minum dibutuhkan oleh manusia, namun dalam kadar berlebih dapat merugikan kesehatan. Sebagai contoh kandungan tembaga $(\mathrm{Cu})$ dalam jumlah kecil diperlukan oleh tubuh untuk metabolisme. Tembaga $(\mathrm{Cu})$ merupakan komponen dari enzim yang diperlukan untuk menghasilkan energi, anti oksidasi dan sintesa hormon adrenalin, serta untuk pembentukan jaringan ikat. Namum kelebihan tembaga $(\mathrm{Cu})$ dalam tubuh akan mengakibatkan keracunan, mual, muntah, dan menyebabkan kerusakan pada hati dan ginjal (Yustisia, 2012). Hasil analisa logam $\mathrm{Cu}$ dalam air minum dalam kemasan dapat dilihat pada gambar 3 di bawah ini.

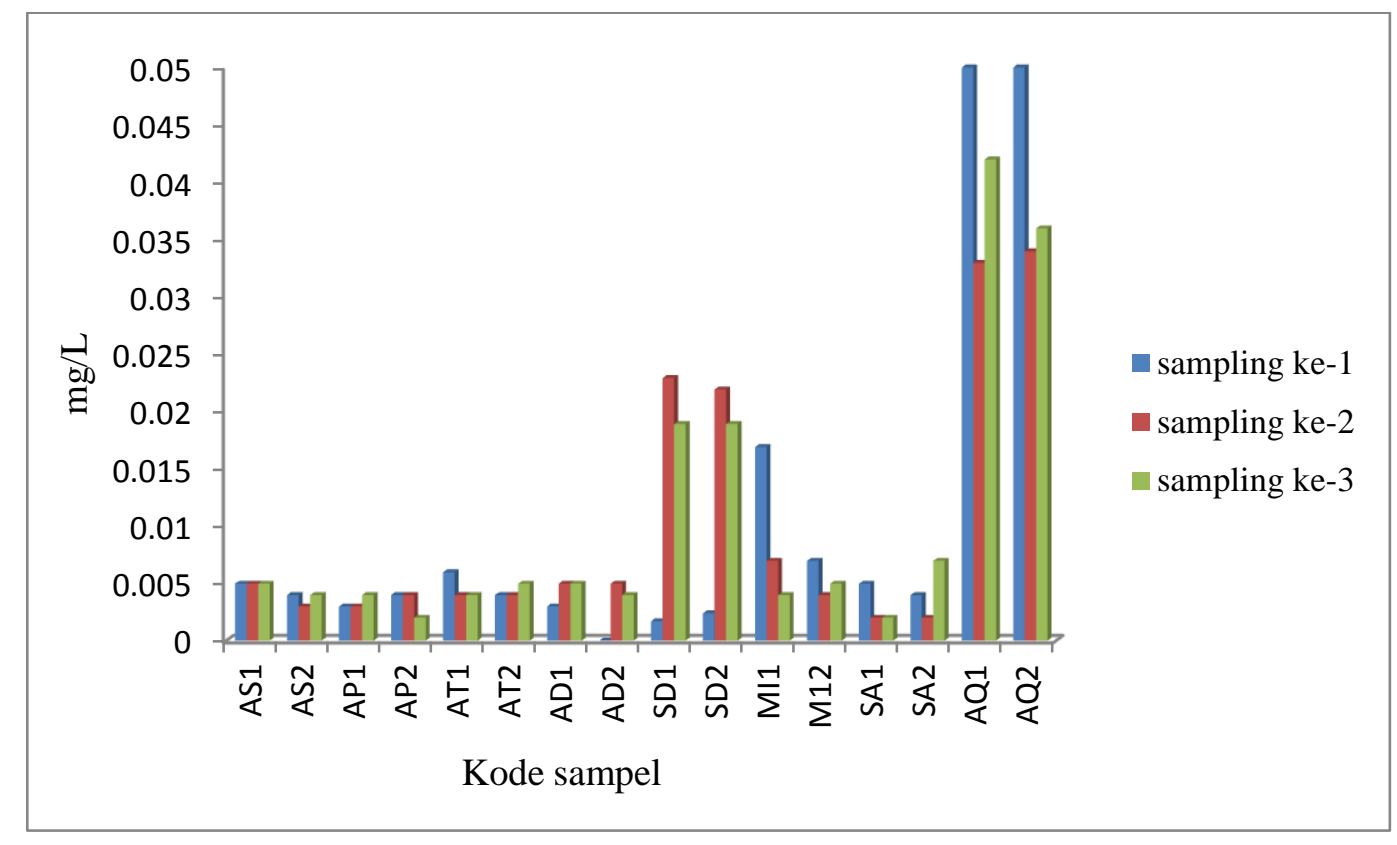

Gambar 3. Hasil analisa Logam Cu

Untuk hasil analisa logam $\mathrm{Cu}$ dapat dilihat pada gambar 3 di atas. Dimana semua merek tidak melebihi kadar logam maksimal yang di tetapkan berdasarkan SNI 013553-2006 tentang air minum dalam kemasan yaitu sebesar 0,5 mg/L. Dimana berdasarkan penelitian diperoleh kadar logam $\mathrm{Cu}$ berkisar antara <0,0014 mg/L sampai $0,05 \mathrm{mg} / \mathrm{L}$.

Salah satu penyebab adanya kandungan logam dalam Air Minum dalam Kemasan, bisa berasal dari pengolahan AMDK yang kurang baik dimana sumber air yang digunakan telah mengandung logam yang bersal dari buang air limbah, erosi, dan dari udara secara langsung (Darmono, 1995). Jika pengolahan sumber air tersebut tidak dilakukan dengan maksimal maka akan manusia yang mengkonsumsinya juga akan ikut terkontaminasi. Menurut Nuraini dkk, Faktor lain yang mempengaruhi 
kandungan logam berat dalam air minum olahan adalah filter (jenis, waktu penggantian, dan kepatuhan operator dalam mengganti filter)(Nuraini, 2015). Hal ini juga bisa menjadi penyebab tingginya kandungan $\mathrm{Cd}$ dalam air minum merek $\mathrm{AQ}$ tersebut. Selain ini faktor lain yang bisa menyebabkan tingginya kandungan logam yang terkandung dalam AMDK tersebut adalah pada saat pengemasan yang kurang higienis.

\section{KESIMPULAN DAN SARAN}

Cemaran logam yang tidak memenuhi syarat karena melebihi batas maksimum yang di tetapkan oleh Standar nasional Indonesia (SNI) untuk Air minum dalam kemasan terkandung dalam AMDK adalah $\mathrm{Cd}$. Terdapat pada air minum merek AQ dengan kadarnya sebesar 0,0065-0,0098 mg/L. Saran untuk penelitian selanjutnya dapat dilakukan penelitian terhadap sumber air minum yang digunakan sebagai air minum dalam kemasan. Sehingga dapat diketahui penyebab awalnya terjadi pencemaran logam.

\section{UCAPAN TERIMA KASIH}

Ucapan terima kasih disampaikan kepada Kementerian Riset dan Pendidikan Tinggi yang telah mendanai penelitian ini melalui Hibah Penelitian Dosen Pemula dengan Nomor kontrak: 07/SP-PEMULA/LPPM/UNRIKA/VI/2017.

\section{REFERENSI}

Amrih, P. 2005. Dua Jam Anda Tahu Cara Memastikan Air yang Anda Minum Bukan Sumber Penyakit. Solo: e-buku 05 - 00001 - 100 - 0220 Distribusi Terbuka. [on line]. www.pitoyo.com. Diakses pada 09 Sepetember 2013.

Anonim, Kumpulan jurnal: Mengenali air, menjaga kualitas produk. Jakarta; Penerbit Wacana Mitra, Edisi 89, 2004.

Darmono, 1995. Logam Berat dalam Sistem Biologi. UI Press. Jakarta.

Järup, L. 2003. Hazards of heavy metal contamination. British Medical Bulletin Vol. 68 Hal:167-182.

Mukono, H. J. 2010. Toksikologi Lingkungan. Airlangga University Press. Surabaya.

Nuraini, iqbal, Sabhan. Analisis Logam Berat dalam Air Minum Isi Ulang (AMIU) dengan menggunakan Spektrofotometri Serapan Atom (SSA). Gravitasi. 14(1), 2015. 36-43.

Soemirat, J. 2004. Kesehatan Lingkungan. Gadjah Mada University Press. Yogyakarta. 
Fitrah Amelia Dan Rahmi : Analisa Logam Berat Pada Air Minum Dalam Kemasan...

Stasys Tautkus, Laura, S., Rolandas, K., Determination of iron in natural and mineral waters by flame atomic absorption spectrometry. J. Serb. Chem. Soc. 69 (5), 2004. 393-402.

Sudjoko, dkk. 2012. Pendidikan lingkungan hidup. Tangerang selatan. Universitas Terbuka.

Widowati, W., Sastiono. A, Jusuf, R. 2008. Efek toksik logam pencegahan dan penanggulangan pencemaran, Yogyakarta: Penerbit andi

Yustisia, A. 2012. Dampak Kelebihan dan Kekurangan Mikronutrien. http;//www.futuremidwife.com. (diakses 22 Februari 2013). 